\title{
ETHNOCULTURAL SPECIFICATION OF KAZAKH ANTROPONYMS WITH SEMI-COMPONENT "GEOGRAPHICAL REALITIES" Orazbaeva E.B. ${ }^{1}$, Niyetbaitegi K.A. ${ }^{2}$ (Republic of Kazakhstan) Email: Orazbaeva338@scientifictext.ru
}

\author{
${ }^{1}$ Orazbaeva Elmira Beisenbaevna - Candidate of Philology; \\ ${ }^{2}$ Niyetbaitegi Kazyna Abenkyzy - Candidate of Philology, Associate Professor, \\ DEPARTMENT OF METHODS OF ELEMENTARY EDUCATION, PEDAGOGICAL AND HUMANITARIAN FACULTY, \\ SOUTH-KAZAKHSTAN STATE PEDAGOGICAL UNIVERSITY, \\ SHYMKENT, REPUBLIC OF KAZAKHSTAN
}

\begin{abstract}
Kazakh anthroponyms, the lexical bases of which are related to the names of geographical realities. The illumination of the subject of the study made it necessary to look at the question through the prism of the way of life of the Kazakhs in the historical past, when the foundation of the community's vital activity was the development of the natural environment, i.e. way of adaptation to the environment. In order to fully elucidate the "reading" of the notion of space by Kazakh nomads, a brief excursion into their economic activities was conducted, the significance of developing the natural environment for nomads is shown. The rich vocabulary of the Kazakh language is described, illustrating the varieties of pastures, types of sites, settlements, common and specific names of grazing places, names of water objects, terrain, micro- and macro-names, which in the process of onimization became anthroponyms. The role of the metaphor accompanying the transition of the appellative to the proper name is shown. Taking into account the fact that the choice of names is a process based on well-known traditions, but at the same time subjective, creative, on specific examples the plurality of motivations of the name of naming is shown. The considered type of personal names testify to the national specificity of Kazakh anthroponymy.
\end{abstract}

Keywords: anthroponimy, motivation, geographical realities, habitat, world perception.

\section{ЭТНОКУЛЬТУРНАЯ СПЕЦИФИКА КАЗАХСКИХ АНТРОПОНИМОВ С СЕМНЫМ КОМПОНЕНТОМ «ГЕОГРАФИЧЕСКИЕ РЕАЛИИ» Оразбаева Э.Б. ${ }^{1}$, Ниетбайтеги К.А.․ㅜ (Республика Казахстан) \\ ${ }^{1}$ Оразбаева Эльмира Бейсенбаевна - кандидат филологических наук, доцент; \\ ${ }^{2}$ Ниетбайтеги Казына Абенкызы - кандидат филологических наук, доцент, кафедра методики начального обучения, педагогико-гуманитарный факультет, Южно-Казахстанский государственный педагогический университет, 2. Шымкент, Республика Казахстан}

\begin{abstract}
Аннотация: в статье рассматривается мотивированность казахских антропонимов, лексические основы которых связаны с наименованиями географических реалий. Освещение предмета исследования обусловило взгляд на вопрос сквозь призму образа жизни казахов в историческом прошлом, когда основу жизнедеятельности общины составляло освоение природной среды, т.е. способ адаптации к среде. Чтобы полнее осветить «прочитывание» понятия пространства казахами-номадами, проведен небольшой экскурс в их хозяйственную деятельность, показана значимость освоения природной среды для кочевников. Описана богатая лексика казахского языка, иллюстрирующая разновидности пастбищ, виды стоянок, поселений, общие и видовые наименования мест выпаса скота, наименования водных объектов, рельеф местности, микро- и макротопонимы, которые в процессе онимизации перешли 8 категорию антропонимов. Показана роль метафоры, сопровождающей переход апеллятива в имя собственное. Принимая во внимание тот факт, что выбор имен - процесс, основанный на известных традициях, но в то же время субъективный, творческий, на конкретных примерах показана множественность мотиваций имянаречения. Рассмотренный тип личных имен свидетельствует о национальной специфичности казахской антропонимии.
\end{abstract}

Ключевые слова: антропонимия, мотивация, географические реалии, среда обитания, мировосприятие.

Одной из ономастических универсалий, характерных для антропонимии многих народов, является именование по месту рождения. Для лингвистической интерпретации категории «географические реалии» в антропонимии актуальным является то, что наряду с исследованием этой категории с универсальных и этнических точек зрения, раскрывается соответствующая этим представлениям языковая картина мира народа. Личным именам свойственна национально-культурная специфика, тесно связанная с мировосприятием народа. 
У казахов обычай давать имя по месту рождения уходит своими корнями в глубокую древность. Жизнедеятельность наших предков-номадов основывалась на скотоводстве и, по мнению этнографов, «зависела от благоприятствующих и неблагоприятствующих обстоятельств природы: климата, почвы, рельефа» [2, с. 12]. В научной литературе подмечена одна существенная деталь в традиционном образе жизни номадов в прошлом - «прямая зависимость различных организационных форм их жизнедеятельности от сезонных колебаний функционального состояния естественной среды обитания» [1, с. 15]. Осваивая Великую степь, скотоводы-кочевники познавали окружающую действительность, интерпретировали ее объекты сквозь призму своего миропонимания. По словам этнографа А. Сейдимбека, степные просторы не только привлекали живущего на ней человека своей бесконечностью, красотой, но и пробуждали, обогащали его сознание, развивали фантазию, мышление [7, с. 111]. Как видим, среда обитания кочевников и географические реалии как его составляющие играли существенную роль в жизни социума, что способствовало обогащению лексики народного языка, в том числе и антропонимии. Формой существования казахов-номадов были общины (аулы), для которых был характерен естественно-натуральный способ производительных сил. Основу жизнедеятельности общины составлял способ адаптации к среде. Хозяйственная деятельность заключалась в выпасе скота в естественных условиях. Зимой скотоводы обитали в зимовках (кыстау), весной скот содержался на весенних пастбищах (коктеу). В мае делали длительные остановки вблизи рек и озер. Через некоторое время, когда скот был уже окрепшим, подрос молодняк, аулы двигались на летние пастбища (жайлау). Осенью аулы перемещались на осенние пастбища (кузеу). Стоянка аула с пастбищем называлась коныс, место стоянки - журт. Скотоводы различали виды пастбищ. В работе Г.К. Конкашпаева «Казахские народные географические термины» обстоятельно описана народная классификация пастбищ [4]. Приведем некоторые примеры наименований: отар - пастбище любого сезона, расположенное вдали от аула (отсюда русское отара, соответствующее современному «отгонный участок»); аныз - жнивье, залет; орай // кокорай - луговые пастбища с обилием воды; урис - выгон, место пастьбы скота, расположенное вокруг аула. Перечисленные выше наименования стоянок и пастбищ, претерпев процесс онимизации, обогатили казахский антропонимикон. Личные имена: Жайлаубай, Кыстаубай, Конысбек, Журтбай, Отарбай, Аныз, Урисбек, Орай являются свидетельствами места рождения детей. Исследователь древнетюркских памятников, топонимист Ш.Т. Куанганов, отметил, что обычай именовать новорожденных по наименованиям местности у тюрков древний и что имена эти несут особую смысловую нагрузку [5, с. 33]. Имя служило как бы фиксацией важного в семье кочевника события.

В качестве ставок степных аристократов использовались оседлые поселения: курган, орда, кент (городища), дуан. Ордой в старину называли временную ставку хана или знатного лица, а позднее это слово стало обозначать «очаг», «центр». По мнению А. Кайдар, корган (от слова коргану «защищаться») возникло вначале как нарицательное название укрепления (вала, крепости), позднее в результате семантической эволюции оно стало обозначать холм, сопку, конусовидную насыпь. Древние крепости и укрепления воздвигались на холмах, возвышенностях, вследствие этого произошел метонимический перенос названия по схеме «курган - укрепление (на холме) - курган - холм» [3, с. 161]. На юге в значении «крепость» употреблялось заимствованное из монгольского жамбыл. Место, где имеются государственные учреждения, называли дуан (перс. «город»). Перечисленные наименования поселений, информируя о месте рождения лица, составили основу личных имен: Ордабай, Корганбек, Жамбыл, Дуангуль.

Немаловажную роль в жизни номадов играла гидросфера. Народная мудрость гласит: «Где вода - там жизнь». Существование всего живого немыслимо без воды, поэтому в сознании народа вода расценивалась как ценность. Аулы располагались обычно в местностях с водоемами. Некоторые наименования водных объектов составили основу личных имен: Дариягуль, Дайрабай (дария и диалектное дайра - ир. «река»), Тенизбай (тениз «море»), Кульбай, Культай (куль «озеро»), Шыганак (шыганак «залив»), Булакбай (булак «родник»), Шайбас (шай - в языке огузской группы «речка»+ «басы» «начало), Арыкбай (арык «канал»), Жагыпар (жагыпар - ар. «родник, ручей»), Мухит (мухит «океан», «окружение, среда»). Употребляясь в основах личных имен, наименования водоемов претерпевают метафоризацию. Благодаря текучести, подвижности, прозрачности, голубоватому как небесная высь цвету вода воспринимается как нечто, расширяющее пространство. Чем больше воды, тем больше пространства, тем глубже дышит человек, потому что его охватывает чувство необъятности, простора, свободы. Может быть, это объясняется и с биологической точки зрения: около воды энергия разряжается. Ономастическое значение упомянутых выше личных имен связано с пожеланием широты души, добродушия.

В антропонимию перешла также лексика, характеризующая рельеф местности: Адырбек (адыр небольшие плоские останцовые возвышенности, разрушенные столовые гряды), Аралбай (Арал «остров, лесной островок в степи, заросли кустарников», имя может быть дано и по топонимиму Арал (море), Сенгирбай (сенгир - ир. «сопки, холмы»), Кумбай (кум «пески»), Уйикбай (уйик «благодатная земля»), 
Жарыкбас (жарыкбас «низменная местность»), Жазира (жазира - ар. «широкая степь»), Ашабай (Аша раздвоенность дороги или рукав реки), Жабырбай (жабыр - др.-т. «просторная, широкая полянка»).

Основу ряда имен составили следующие географические реалии: Ормантай (орман «лес»), Тогайбай (тогай «небольшой лес, роща»), Откелбай (откел «переправа»), Таубай, Таужан, Таутай. Наличие в антропонимах компонента «тау» и лексем, обозначающих холмы, возвышенности, является лингвистическим свидетельством функционирования в историческом прошлом народа культа гор, холмов.

Древняя традиция именования по месту рождения продолжается и в наше время. В современном казахском антропонимиконе имеется масса имен, образованных от топонимов. Многие имена восходят к названиям микротопонимов:

а) урочищ: Жаманкара, Жолан, Байшуак, Кармыс;

б) летовок: Елшибек, Текебай, Кодар; Игисин;

в) населенных пунктов: Макатай (Атырауская обл.), Байкадам (НП в Жамбылской и Кызылординской обл.), Бактыбай (Карагандинская обл.);

г) отрогов: Сугирбай (Сугир - в Алматинской обл), Пушантай (Чингисские отроги в ВосточноКазахстанской обл.);

д) холмов: Мыржык (в Сарыарке), Балабек (названия многих холмов);

е) перевалов: Кайкы (в Алматинской обл.), Алаяк (во многих местах); обл.)

ж) небольших озер: Итаяк (в Сарыарке), Байеке (в Костанайской обл.), Тезекбай (В Акмолинской

3) речек: Шорман (в Акмолинской обл.), Келес (в Южно-Казахстанской обл.), Байкабыл (в Костанайской обл.).

Процессом трансонимизации охвачены и макротопонимы: Едилбай (по древнетюркскому названию р. Волги), Ертисбай (р. Иртыш), Торгай (река и плато Торгай), Оралхан (р. Урал), Алтай (гора Алтай), Мадина (г. Медина), Арапат (священная гора Арафат), Шымкентбай (г. Шымкент). Развитие дружеских, культурных, экономических, политических связей Казахстана с другими странами расширило состав казахских топоантропонимов. По топонимам постсоветского пространства образованы имена: Ташкенбай (г. Ташкент), Маскеу (г. Москва), Ереван (г. Ереван), Самарқан (г. Самарканд), Баку (г. Баку). Основу личных имен составили и названия государств, городов зарубежья: Куба, Иран, Ирак, Багдат, Рим, Марсель. Именование по известным топонимам объясняется их популярностью, а также актуальностью событий, происходивших в этих странах, городах в момент появления на свет носителя имени.

Принимая во внимание тот факт, что выбор имен - процесс, основанный на известных традициях, но в то же время субъективный, творческий, следует признать разные мотивации имянаречения. Так, академик А. Маргулан в своих этнографических записках писал: «С. дал своему сыну имя Самаркан в связи с тем, что в момент его рождения он читал книгу про город Самарканд; женщина Токсан получила свое имя в связи с тем, что родилась во время перекочевки возле колодца Токсан [6, с. 229]. Имя Крымбек, к примеру, было дано мальчику, родившемуся во время отдыха отца в Крыму.

Многие антропонимы допускают несколько толкований. Так, личное имя Манат могло образоваться по названию аула в Восточно-Казахстанской области, в свою очередь восходящего к этнониму, а также по наименованию ткани типа фланели. Имя Бескемпир могло быть дано по названию урочища или по родовой подгруппе казахов. Имя Токпакбай может восходить к этнониму, родовой группе найманов или к наименованию холодного оружия, использовавшегося в прошлом.

Представляет интерес связь между отантропонимными и оттопонимными образованиями. Наименование урочища Дандыбай в центральной части республики происходит от личного имени, а функционирующее в современной антропонимии имя Дандыбай, конечно, восходит к топониму.

Таким образом, мотивацию личных имен описанного типа следует рассматривать в этнокультурном аспекте, поскольку антропонимия народа формируется на протяжении веков и является хранилищем информации об истории этноса, его традициях, быте, культуре.

\section{Список литературы / References}

1. Алимбай Н., Муканов М.С., Аргынбаев Х. Традиционная культура жизнеобеспечения казахов. Очерки теории и истории. Алматы: Гылым, 1998. 234 с.

2. Гачев Г. Путешествие в казахский космос. Семей: Международный клуб Абая, 2002. 218 с.

3. Кайдар А. Актуальные вопросы казахского языка. Алматы: Ана тили, 1998. 304 с.

4. Конкашпаев Г.К. Казахские народные географические термины. // Изв. АН Каз ССР. Серия геогр., 1951. Вып. 3. С. 3-47.

5. Куанганов Ш.Т. «Арий-гунн» сквозь века и пространство: свидетельства, топонимы. Астана: Фолиант, 2001. 252 с. 
6. Маргулан А. Культура и быт казахского колхозного аула. Алма-Ата: «Наука» Каз. ССР, 1967. 303 с.

7. Сейдимбек А. Мир казахов. Учебное пособие. Алматы: Санат, 1997. 464 с. 